\title{
Comparative Review of Consensus-Based Clinical Target Volume Definitions for Prostate Radiotherapy
}

\author{
Graham Smith $^{1}$, George Rodrigues ${ }^{2}$
}

1. Department of Epidemiology and Biostatistics, Western University, London ON, Canada, N6A 5C1 2. Department of Radiation Oncology, London Regional Cancer Program, London, Ontario, CA; Schulich School of Medicine \& Dentistry, Western University, London, Ontario, CA

$\square$ Corresponding author: George Rodrigues, george.rodrigues@lhsc.on.ca Disclosures can be found in Additional Information at the end of the article

\section{Abstract}

Background: A major obstacle in the delivery of postoperative radiation therapy (RT) for prostate cancer is accurate delineation of the tumor targets and organs at risk. Although postoperative prostate cancer contouring atlases are quite common, there is still no widely accepted contouring guideline. The purpose of this study is to critically review the various postoperative prostate RT treatment planning consensus guidelines or atlases currently available.

Methods: A literature search was conducted using various electronic databases with the key terms: prostate, contour, planning tumour volume, clinical target volume, delineation or definition, guidelines or atlas, and radiation oncology. The search was limited to English publications from the years 1985 to 2011.

Results: A total of seven publications relating to contouring guidelines for postoperative prostate radiotherapy were identified. There are four distinct consensus guidelines developed by major institutions: Princess Margaret Hospital, the Australian and New Zealand Radiation Oncology Genito-Urinary Group, the European Organization for Research and Treatment of Cancer, and the Radiation Therapy Oncology Group.

Conclusions: After reviewing the consensus contouring guidelines for postoperative prostate cancer radiation therapy that were available in the literature, it is clear that there disagreement with regards to what anatomical borders should be used for delineating an appropriate prostate bed CTV. Additional studies comparing the reproducibility of the various guidelines as well as the performance of these guidelines on clinically important outcomes are needed.

Received 07/16/2013

Review began 07/16/2013

Published 07/18/2013

@ Copyright 2013

Smith et al. This is an open access article distributed under the terms of the Creative Commons Attribution License CC-BY 3.0., which permits unrestricted use, distribution, and reproduction in any medium, provided the original author and source are credited.
Categories: Radiation Oncology, Urology, Epidemiology/Public Health

Keywords: clinical target volume, prostate cancer, contouring, guidelines, radiation therapy, consensus guidelines

\section{Introduction}

Postoperative radiation therapy (RT) is indicated in the treatment of post-prostatectomy patients with high-risk of local recurrence [1]. Recent studies have shown RT to be beneficial following radical prostatectomy in both the adjuvant setting, for patients with high-risk pathological features, such as positive surgical margins and seminal vesicle invasion [2-8], or as 
salvage for biochemical disease recurrence [9-10]. Two randomised controlled trials suggest adjuvant RT directly following surgery provides improved progression-free survival, biochemical relapse-free survival, and local control over watchful waiting protocols [3, 11]. Although a long-term follow-up of one of these trials also suggests that adjuvant RT also improves metastasis-free survival and overall survival compared with observation alone [2], there is insufficient long-term follow-up data available to adequately assess the effect on these treatment outcomes.

A major obstacle in the delivery of postoperative radiation therapy for prostate cancer is accurate delineation of the tumor targets and Organs at Risk (OARs). Inter-observer variability between oncologist drawn contours in prostate radiation therapy is well documented [12-15] and has been identified as a highly significant contributing factor to uncertainty in radiation therapy treatment planning [16]. Contouring consensus guidelines or atlases for postoperative prostate RT have been created to aid oncologists in the delineation of tumor targets and OARs with the hope of reducing this variability.

Although postoperative prostate cancer contouring atlases are quite common, there is still no widely accepted contouring guideline. The purpose of this study is to critically review the various postoperative prostate RT treatment planning consensus guidelines or atlases currently available with emphases on the methodology and validity of each atlas.

\section{Materials And Methods}

A literature search was conducted using the electronic databases Pubmed, MEDLINE (OVID), EMBASE, Cochrane Library, and Google Scholar with the key terms: prostate, contour, planning tumour volume, clinical target volume, delineation or definition, guidelines or atlas, and radiation oncology. The search was limited to English publications from the years 1985 to 2011. Relevant studies found on references lists of identified articles were included as well as any articles found on national cooperative group websites, including the Radiation Therapy Oncology Group (RTOG) and European Organization for Research and Treatment of Cancer (EORTC). Only studies related to medicine or physics (including radiation oncology, imaging, oncology or cancer) were included. The methodology used in these articles including how each consensus was reached and study validity was reviewed, and any similarities and differences found in the contouring guidelines were detailed.

\section{Results}

\section{Literature search}

A total of seven publications relating to contouring guidelines for postoperative prostate radiotherapy were identified [17-23]. There are four distinct consensus guidelines developed by major institutions: Princess Margaret Hospital (PMH) [17], the Australian and New Zealand Radiation Oncology Genito-Urinary Group (FROGG) [19], the European Organization for Research and Treatment of Cancer (EORTC) [21], and the Radiation Therapy Oncology Group (RTOG) [22]. A fifth consensus statement was identified from the Radiotherapy and Androgen Deprivation In Combination After Local Surgery (RADICALS) group in their validation study [18], in which they used a modified version of the PMH consensus guideline. No publication outlining the contents of this version was found. There were five studies discussing the methodology used in the creation of the various consensus statements [17, 19, 21-23]. The information from the EORTC consensus was published in two separate articles [21, 23]. There were two validation publications, one from the RADICALS [18] and the other from EORTC [20]. The study by PMH [17] contains both a description of how their consensus was reached as well as a validation component. Although the article from Boehmer, et al. [23] was on guidelines for radiotherapy for intact prostate, it was referred to in the EORTC consensus for 


\section{Cureus}

postoperative prostate radiotherapy by Poortman, et al. [21] and was included in this review. The studies were published between 2006 and 2011 and represent a large number of medical institutions from a wide range of countries (Table 1).

\begin{tabular}{|c|c|c|c|c|c|}
\hline $\begin{array}{l}\text { Primary } \\
\text { Author }\end{array}$ & $\begin{array}{l}\text { Primary Oncology } \\
\text { Group/Institution } \\
\text { Responsible for } \\
\text { Consensus }\end{array}$ & Countries Involved & $\begin{array}{l}\text { Date } \\
\text { Published }\end{array}$ & $\begin{array}{l}\text { Number of } \\
\text { Medical } \\
\text { Institutions } \\
\text { Involved }\end{array}$ & $\begin{array}{l}\text { Consensus [C] } \\
\text { and/or } \\
\text { Validation [V] } \\
\text { Study }\end{array}$ \\
\hline $\begin{array}{l}\text { K. } \\
\text { Wiltshire }\end{array}$ & PMH & $\begin{array}{l}\text { Australia, Canada, } \\
\text { Switzerland }\end{array}$ & 2007 & 4 & $\mathrm{C}, \mathrm{V}$ \\
\hline D. Mitchell & RADICALS & United Kingdom & 2009 & 2 & v \\
\hline M. Sidhom & FROGG-RANZCR & $\begin{array}{l}\text { Australia, Singapore, New } \\
\text { Zealand }\end{array}$ & 2008 & 7 & C \\
\hline P. Ost & EORTC & Belgium & 2011 & 1 & V \\
\hline $\begin{array}{l}\text { P. } \\
\text { Poortmans }\end{array}$ & EORTC & $\begin{array}{l}\text { Belgium, France, Germany, } \\
\text { Netherlands, Switzerland, } \\
\text { United Kingdom }\end{array}$ & 2007 & 13 & C \\
\hline $\begin{array}{l}\text { J. } \\
\text { Michalski }\end{array}$ & RTOG & Canada, USA & 2010 & 13 & $\mathrm{C}$ \\
\hline $\begin{array}{l}\text { D. } \\
\text { Boehmer* }\end{array}$ & EORTC & $\begin{array}{l}\text { Belgium, France, Germany, } \\
\text { Netherlands, Switzerland, } \\
\text { United Kingdom }\end{array}$ & 2006 & 10 & C \\
\hline
\end{tabular}

\section{TABLE 1: Post-operative prostate radiation therapy contouring consensus guideline publications}

Abbreviations: $\mathrm{PMH}=$ Princess Margaret Hospital; RADICALS = Radiotherapy and Androgen Deprivation In Combination After Local Surgery; EORTC = European Organization for Research and Treatment of Cancer; RTOG = Radiation Therapy Oncology Group; FROGG-RANZCR = The Faculty of Radiation Oncology Genito-Urinary Group part of the Royal Australian and New Zealand College of Radiologists. * European Organization for Research and Treatment of Cancer consensus guidelines for intact prostate

\section{Discussion}

\section{Consensus methodology}

The methodology for creating the consensus atlases by the RTOG, FROGG and PMH began with delineation of preliminary contours by a small group of clinicians, involving at least one oncologist or urologist experienced with postoperative prostate radiotherapy or prostatectomy $[17,19,22]$. In these studies, the clinicians responsible for delineating the initial contours were given patients with specific clinical scenarios and were asked to delineate an appropriate clinical target volume (CTV) based on their expert knowledge of anatomy, tumor physiology and patterns of spread [17, 19, 22]. Consensus guidelines from the RTOG, FROGG and PMH were finalized following a presentation and discussion of their preliminary contours at a conference or consensus workshop [17, 19, 22]. Inter-professional collaboration between diverse multidisciplinary groups of health care professionals, specifically individuals with expertise in the 
treatment of prostate cancer, was utilized in the creation of the consensus atlases $[17,19,21$ 23]. The study by PMH focused on postoperative prostate patients with or without seminal vesicle invasion [17], while the RTOG study focused on the clinical scenarios of seminal vesicle invasion and positive apex margins [22]. A review of relevant literature was present in the development of each of the consensus guidelines [17, 19, 21-23].

The initial contours generated by PMH were presented at the Australian Faculty of Radiation Oncology Genito-Urinary Oncology Group Consensus Workshop on Post-Prostatectomy Radiotherapy in June 2006 [17, 19]. The consensus guidelines created at this conference were further modified by the FROGG and were used in the creation of their own consensus atlas [19].

The RTOG used an imputation method of the expected maximum (EM) algorithms for simultaneous truth and performance level estimation (STAPLE) [24] to create their preliminary contours. The STAPLE algorithm has been previously identified as a useful tool in analyzing expert radiation oncologist consensus contours [25]. The RTOG STAPLE contours were presented at a RTOG conference where they were discussed and a consensus was finalized following a teleconference [22].

There was no information given by the EORTC regarding the exact process in which their consensus guideline was reached. Instead, the EORTC presents detailed manuscripts reviewing published works relevant to prostate cancer, specifically studies on surgery, anatomy and local recurrence $[21,23]$.

A detailed description of the methods involved in the creation of the four contouring guidelines is shown in Table 2 . 


\section{Cureus}

\section{Consensus How Consensus was Reached}

Three urologists experienced with open or laparoscopic prostatectomy independently delineated the anatomical borders of the prostate bed at risk of microscopic cancer seeding on axial MRI scans of 2 patients (with and without seminal vesicles, selected randomly from the patient population) and presented these contours to a multi-disciplinary Genito-Urinary (GU) tumor board. An Interdisciplinary discussion between all members of the GU board including radiation oncologists, medical oncologists,

Wiltshire et urologists, uroradiologists and uropathologists occurred and a review of the literature (patterns of al (PMH) failure, surgical practice, radiologic anatomy) was completed. Final consensus CTV was defined by 1 uroradiologist and 2 radiation oncologists and was approved by a GU board containing 10 rad oncologists, 4 urologists and 1 uroradiologist. Consensus was modified further following presentations of consensus at Australian Faculty of Radiation Oncology Genito-Urinary Oncology Group Consensus Workshop on Post Prostatectomy Radiotherapy June 2006 and Genito-Urinary Radiation Oncologists of Canada Meeting January 2007.

Consensus was reached following a 2-day consensus workshop. Prior to workshop extensive literature review was performed which led FROGG executives to generate a draft of post-prostatectomy

FROGGguidelines. Guidelines from PMH were presented at the conference, discussed and refined. Expert RANZCR speakers from radiation oncology, urology and radiology presented data on topics relevant to postprostatectomy radiotherapy at 2-day workshop. 63 delegates from Radiation Oncology, Radiology, Urology, Medical Physics, and Radiation Therapy attended. Unresolved issues handled by workshop parties for final revision

11 oncologist observers contoured 2 post-op prostate patients with 2 separate clinical scenario cases: 1) positive apex margin or 2) invasion of seminal vesicles and evaluated the inter-observer variability between oncologists (each oncologist was to use their own institution's contouring policy). From these contours they used an imputation method of the expected maximum (EM) algorithms for

RTOG simultaneous truth and performance level estimation (STAPLE), to create a consensus contour derived from the collection of observer contours. The STAPLE contour represents the 'true' contour for each patient. The RTOG held a conference where they presented a review of patterns of failure, anatomy and surgical findings related to radical prostatectomy. Each STAPLE contour (for each patient case) was used as a starting point for discussion and creation of consensus guidelines. The RTOG reviewed and modified the consensus contours at a conference and finalized them via teleconference.

EORTC

Presented a manuscript reviewing published work on local recurrence sites in post-op prostate cancer, surgery and anatomy. It is unclear as to how their consensus was reached.

\section{TABLE 2: Description of consensus guideline methodology}

Abbreviations: PMH = Princess Margaret Hospital; RADICALS = Radiotherapy and Androgen Deprivation In Combination After Local Surgery; EORTC = European Organization for Research and Treatment of Cancer; RTOG = Radiation Therapy Oncology Group; FROGG-RANZCR = The Faculty of Radiation Oncology Genito-Urinary Group part of the Royal Australian and New Zealand College of Radiologists.

\section{Validation studies}

There were three publications validating consensus guidelines for postoperative prostate radiotherapy found in the literature $[17-18,20]$. Consensus statements from the EORTC, PMH as well as a modified version of the PMH consensus (RADICALS) were evaluated in these studies [17-18, 20]. There were no validation studies found from the RTOG or the FROGG. A summary of the validation studies is presented in Table 3. 


\section{Cureus}

\begin{tabular}{|c|c|c|c|}
\hline $\begin{array}{l}\text { Author } \\
\text { (Country) }\end{array}$ & $\begin{array}{l}\text { Consensus } \\
\text { Validated }\end{array}$ & $\begin{array}{l}\text { Study } \\
\text { Population } \\
\text { (\# } \\
\text { Patients) }\end{array}$ & $\begin{array}{l}\text { Health Care } \\
\text { Professiona } \\
\text { Involved (\#) }\end{array}$ \\
\hline $\begin{array}{l}\text { Wiltshire } \\
\text { et al } \\
\text { (Canada) }\end{array}$ & PMH & $\begin{array}{l}\text { Study 1) } 25 \\
\text { Study 2) } 16 \\
\text { Study 3) } 20\end{array}$ & $\begin{array}{l}\text { Study 1) } 3 \\
\text { oncologist } \\
\text { observers. } \\
\text { Study 2) } 2 \\
\text { oncologist } \\
\text { observers. } \\
\text { Study 3) No } \\
\text { information } \\
\text { given. }\end{array}$ \\
\hline
\end{tabular}

Mitchell

et al

(United

*RADICALS 3

Kingdom)

\section{Study 1) Assessing} consensus CTV coverage using prostate bed surgical clips. Study 2) Intra- and inter-observer variability study to determine reproducibility of consensus. Study 3) Retrospective study to determine the impact of the consensus guidelines on clinical practice using dose volume histograms.

\section{Compared CTV sizes} before and after contouring guideline use. Inter-observer variability study to compare observer contours using the coefficient of variation statistical method. A comparison using Maximum Volume Ratio (MVR) to determine the greatest extent of difference between the volumes before and after the use of guidelines was made.

Inter-observer variability study. Volumes were compared using an open-source Matlabbased radiation
Study 1) Surgical clips well distributed, with a lower clip density appreciated at anterior- superior and posterior-most extent of CTV.

Surgical Clips were contained (338 out of 339 clips) within consensus CTV. Study 2) Small systematic interobserver errors were observed in the AP dimension. Most uncertainty was observed in superior/posterior/lateral aspect of CTV. Intra- and interobserver variability was described as random and not systemic. Study 3 ) CTV volume and field size increased with consensus. Less that $50 \%$ of patients received prescribed microscopic dose (V100 >95\%)

CTV increased in size with reduced inter-observer variability in treatment plan contours 


\section{Cureus}

\begin{tabular}{|c|c|c|c|c|c|}
\hline $\begin{array}{l}\text { Ost et al } \\
\text { (Belgium) }\end{array}$ & EORTC & 10 & $\begin{array}{l}\text { and } 5 \\
\text { radiation } \\
\text { oncologist } \\
\text { observers. }\end{array}$ & $\begin{array}{l}\text { therapy planning } \\
\text { analysis statistical } \\
\text { tool for agreement } \\
\text { (apparent volume of } \\
\text { overlap corrected } \\
\text { using kappa } \\
\text { statistics) to } \\
\text { determine if EORTC } \\
\text { guidelines reduced } \\
\text { variation in contours. }\end{array}$ & $\begin{array}{l}\text { Guidelines show moderate inter- } \\
\text { observer agreement (mean kappa, } \\
0.49 \text { ) and refinement of EORTC } \\
\text { guidelines were recommended. }\end{array}$ \\
\hline
\end{tabular}

\section{TABLE 3: Consensus Guideline Validation Studies}

Abbreviations: PMH = Princess Margaret Hospital; RADICALS = Radiotherapy and Androgen Deprivation In Combination After Local Surgery; EORTC = European Organization for Research and Treatment of Cancer; CTV = Clinical Target Volume. * Modified Princess Margaret Hospital consensus guidelines.

The publication from PMH validates their consensus in three separate studies [17].

The first validation study assessed the coverage of the consensus Clinical Target Volume (CTV) relative to prostate bed surgical clips placed during routine clinical practice at their institution. There were 25 postoperative prostate patients with a total of 339 surgical clips in the entire patient cohort. A single observer was responsible for delineating an appropriate CTV for each patient using the PMH consensus guidelines, while a second observer was responsible for identifying the surgical clip co-ordinates on CT scans for each patient [17]. To visualize how well the surgical clips were contained within the consensus contours deformable registration and a finite element modeling (FEM) method, (Mofeus), [26] was used to generate a single CTV representing the entire cohort to evaluate its coverage of the surgical clips [17]. Results showed all surgical clips were contained within the consensus CTV, minus one outlier, and the distribution throughout the CTV was uniformly observed, with a lower clip density appreciated at the anterior-superior and posterior-most aspects [17].

The second validation looked at the intra- and inter-observer reproducibility of the consensus contours. Two observers individually contoured 16 patients on MRI and CT scans and repeated this at least one week later [17]. The reproducibility of the contours was assessed using the finite element modeling (FEM) method, Morfeus, statistical tool used previously in their first validation study [26]. The variation in observer contours were said to be "mainly random" with small systematic inter-observer errors observed in the Anterior-Posterior (AP) dimension [17].

The third PMH validation study involved a retrospective analysis of the effects of the consensus guidelines on clinical practice. Twenty patients previously treated with various techniques of postoperative radiotherapy (including one or two phase four-field box or Intensity Modulated Radiation Therapy) were re-planned using the PMH consensus guidelines. The newly created plans were compared both volumetrically and dosimetrically to the original plans used for treatment. An increase in both the contour volumes and field sizes was observed in the consensus plans and only $50 \%$ of the patients would have received the prescribed microscopic dose $\left(\mathrm{V}_{100}>95 \%\right)$ to the CTV in these plans [17].

The validation study by Ost, et al. assessed whether adopting the EORTC consensus guidelines would reduce inter-observer contouring variability at their institution. Ost, et al. compared the 


\section{Cureus}

contours of 10 patients, delineated by six observers (five radiation oncologists and one radiologist) using the EORTC guidelines [20]. The variability was assessed using an opensource Matlab-based radiation therapy planning analysis statistical tool [27] for agreement (volume of overlap corrected using kappa statistics) [28]. The specificity and sensitivity of the observer contours with and without the contouring guidelines was evaluated using the STAPLE method [24]. Variation in dimensions of observer contours in the superior, inferior, anterior, posterior, and lateral margins were assed by comparing the distances of the outer margins of each CTV to a pre-determined centre point [20]. The inferior margin variability was assed by comparing the inferior border distance to the penile bulb delineated on MRI. Ost, et al. described the overall inter-observer agreement for the CTVs using the EORTC guidelines as moderate (mean kappa, 0.49), and recommended a refinement of the EORTC consensus atlas [20].

The modified PMH consensus guidelines assessed by Mitchell, et al. on behalf of the RADICALS were not defined in their study or found in the literature. Mitchell, et al. found that using the RADICALS consensus guidelines led to an increase in the volume of the CTV and there was a reduction in inter-observer variability [18].

\section{Target volume definitions}

The consensus information regarding the margins adopted by each institution is displayed in Table 4. Consensus statements from PMH, FROGG and the RTOG focused on border landmarks in their consensus $[17,19,22]$, while the EORTC included areas at greatest risk for relapse in their CTV guidelines $[21,23]$.

\begin{tabular}{|c|c|c|c|c|c|}
\hline Consensus & Superior Margin & Inferior Margin & Lateral Margin & $\begin{array}{l}\text { Anterior } \\
\text { Margin }\end{array}$ & $\begin{array}{l}\text { Posterior } \\
\text { Margin }\end{array}$ \\
\hline $\begin{array}{l}\text { Wiltshire et } \\
\text { al (PMH) }\end{array}$ & $\begin{array}{l}\text { Superior surgical } \\
\text { clips (if present) or } 5 \\
\text { mm above the } \\
\text { inferior border of the } \\
\text { vas deferens. } \\
\text { Include seminal } \\
\text { vesicles when } \\
\text { pathologically } \\
\text { involved. }\end{array}$ & $\begin{array}{l}\text { 8mm below VUA or top } \\
\text { of Penile Bulb (PB) } \\
\text { (whichever is most } \\
\text { superior). }\end{array}$ & $\begin{array}{l}\text { Medial boarder of } \\
\text { levator ani and } \\
\text { obturator internus } \\
\text { (caudal); } \\
\text { Sacrorectogenitopubic } \\
\text { fascia, lateral to the } \\
\text { neurovascular } \\
\text { structures (cranial). }\end{array}$ & $\begin{array}{l}\text { Posterior } \\
\text { edge of } \\
\text { symphysis } \\
\text { pubis to top } \\
\text { of symphysis } \\
\text { pubis } \\
\text { (caudal); } \\
\text { Posterior } \\
1.5 \mathrm{~cm} \text { of } \\
\text { bladder wall } \\
\text { (cranial). }\end{array}$ & $\begin{array}{l}\text { Anterior } \\
\text { rectal wall } \\
\text { and levator } \\
\text { ani (caudal); } \\
\text { Mesorectal } \\
\text { fascia } \\
\text { (cranial). }\end{array}$ \\
\hline $\begin{array}{l}\text { FROGG- } \\
\text { RANZCR }\end{array}$ & $\begin{array}{l}\text { Encompass all of } \\
\text { the seminal vesicle } \\
\text { bed as defined by } \\
\text { non-vascular clips } \\
\text { and should include } \\
\text { the distal portion of } \\
\text { the vas deferens. } \\
\text { Include seminal } \\
\text { vesicles if } \\
\text { pathologically } \\
\text { involved. }\end{array}$ & $\begin{array}{l}5-6 \mathrm{~mm} \text { below the } \\
\text { vesicourethral } \\
\text { anastomosis (extended } \\
\text { lower to include all } \\
\text { surgical clips). When } \\
\text { VUA is poorly defined } \\
\text { INF border will be the } \\
\text { slice above the penile } \\
\text { bulb. }\end{array}$ & $\begin{array}{l}\text { The medial border of } \\
\text { the levator ani or } \\
\text { obturator internus. }\end{array}$ & $\begin{array}{l}\text { Posterior } \\
\text { edge of } \\
\text { symphysis } \\
\text { pubis } \\
\text { (caudal); } \\
\text { Posterior } 1.5 \\
\text { cm of the } \\
\text { bladder } \\
\text { (cranial). }\end{array}$ & $\begin{array}{l}\text { Anterior } \\
\text { rectal wall } \\
\text { and levator } \\
\text { ani (caudal); } \\
\text { Anterior } \\
\text { mesorectal } \\
\text { fascia } \\
\text { (cranial). }\end{array}$ \\
\hline
\end{tabular}




\section{Cureus}

\begin{tabular}{|c|c|c|c|c|c|}
\hline EORTC & $\begin{array}{l}\text { Bladder neck and } \\
\text { up to base of } \\
\text { seminal vesicles } \\
\text { Include seminal } \\
\text { vesicles if } \\
\text { pathologically } \\
\text { involved. }\end{array}$ & $\begin{array}{l}15 \mathrm{~mm} \text { cranially from the } \\
\text { penile bulb or at the } \\
\text { apex. }\end{array}$ & $\begin{array}{l}\text { Include up to the } \\
\text { neurovascular bundles } \\
\text { (if removed up to the } \\
\text { ilio-obturatic muscles). }\end{array}$ & $\begin{array}{l}\text { Include } \\
\text { anastomosis } \\
\text { and the } \\
\text { urethral axis. }\end{array}$ & $\begin{array}{l}\text { Up to but } \\
\text { not } \\
\text { including } \\
\text { the outer } \\
\text { rectal wall } \\
\text { (caudal); } \\
\text { Most } \\
\text { posterior } \\
\text { part of the } \\
\text { bladder } \\
\text { (cranial). }\end{array}$ \\
\hline RTOG & $\begin{array}{l}\text { Level of cut end of } \\
\text { vas deferens or 3-4 } \\
\mathrm{cm} \text { above top of } \\
\text { symphysis (Vas may } \\
\text { retract } \\
\text { postoperatively). } \\
\text { Include seminal } \\
\text { vesicle if } \\
\text { pathologically } \\
\text { involved. }\end{array}$ & $\begin{array}{l}\text { 8-12 mm below } \\
\text { vesicourethral } \\
\text { anastomosis (May } \\
\text { include more if concern } \\
\text { for apical margin). Can } \\
\text { extend to slice above } \\
\text { penile bulb if } \\
\text { vesicourethral } \\
\text { anastomosis not well } \\
\text { visualized. }\end{array}$ & $\begin{array}{l}\text { Levator ani and } \\
\text { obturator internus } \\
\text { (caudal); } \\
\text { Sacrorectogenitopubic } \\
\text { fascia (cranial). If } \\
\text { concern about } \\
\text { extraprostatic disease } \\
\text { at base may extend to } \\
\text { obturator internus. }\end{array}$ & $\begin{array}{l}\text { Posterior } \\
\text { edge of } \\
\text { pubic bone } \\
\text { (caudal); } \\
\text { Post 1-2 cm } \\
\text { of bladder } \\
\text { wall (cranial). }\end{array}$ & $\begin{array}{l}\text { Anterior } \\
\text { rectal wall } \\
\text { (caudal) - } \\
\text { May need to } \\
\text { be concave } \\
\text { around } \\
\text { lateral } \\
\text { aspects; } \\
\text { Mesorectal } \\
\text { fascia } \\
\text { (cranial). }\end{array}$ \\
\hline
\end{tabular}

\section{TABLE 4: CTV margin recommendations from consensus guideline atlases}

Abbreviations: $\mathrm{PMH}=$ Princess Margaret Hospital; EORTC = European Organization for Research and Treatment of Cancer; RTOG = Radiation Therapy Oncology Group; FROGG-RANZCR = The Faculty of Radiation Oncology Genito-Urinary Group part of the Royal Australian and New Zealand College of Radiologists.

Superior Margin:

The anatomical landmarks used as the superior boundary in the consensus statements were the level of the cut end of the vas deferens [17, 19, 22] or the bladder neck up to the base of the seminal vesicles [21]. The superiorly located prostate bed surgical clips were included in the superior margin by PMH and FROGG [17, 19]. PMH recommends a $5 \mathrm{~mm}$ margin above the vas deferens as an alternative superior margin in the absence of surgical clips or when the vas deferens is poorly visualized [17]. If the vas deferens retracts posteriorly, the RTOG suggests using a superior margin 3-4 cm above the top of the pubic symphysis [22]. The EORTC recommends the bladder neck up to the base of the seminal vesicles be included in the prostate bed CTV [21].

Inferior Margin:

There were two methods used to delineate the inferior border in the consensus guidelines, involving either a designated distance below the vesicourethral anastomosis (VUA) [17, 19, 22], or slightly above the penile bulb or at the apex [21]. The measurements chosen for the distance below the VUA ranged from 5-6 mm [19] to 8-12mm [22]. The penile bulb was chosen as an alternative landmark for defining the inferior border by PMH, FROGG and the RTOG in the event that the VUA is poorly visualized [17, 19, 22]. 


\section{Cureus}

\section{Lateral Margin:}

The lateral margin chosen by PMH, FROGG and the RTOG was the levator ani and obturator muscles (caudally), and the Sacrorectogenitopubic fascia (cranially) [17, 19, 22]. The EORTC chose the neurovascular bundles as their lateral border [21].

Anterior Margin:

The anterior margin chosen by PMH, FROGG and the RTOG was the posterior edge of the pubic symphysis (caudally) and the posterior bladder wall (cranially) [17, 19, 22]. The anterior margin from the EORTC includes the anastomosis and the urethral axis [21].

Posterior Margin:

All four institutions chose the anterior rectal wall for the posterior, caudal border [17, 19, 21 22]. The mesorectal fascia was chosen by PMH, FROGG and the RTOG for the posterior cranial border [17, 19, 22], while the EORTC chose the posterior bladder [21].

\section{Additional consensus information}

Information regarding the imaging technology, patient positioning, vesicourethral anastomosis (VUA) visualization method, organs at risk (OARs), and additional target volume recommendations from the consensus guidelines are displayed in Table 5.

\begin{tabular}{|c|c|c|c|c|c|}
\hline Consensus & Imaging Technology & $\begin{array}{l}\text { Patient } \\
\text { Positioning } \\
\text { and Organ } \\
\text { Prep }\end{array}$ & $\begin{array}{l}\text { VUA } \\
\text { Visualization } \\
\text { Method }\end{array}$ & OARs & $\begin{array}{l}\text { Additional CTV and PTV } \\
\text { recommendations }\end{array}$ \\
\hline $\begin{array}{l}\text { Wiltshire et } \\
\text { al (PMH) }\end{array}$ & $\begin{array}{l}\text { Axial, pelvic, helical } \\
\text { CT ( } 2 \mathrm{~mm} \text { thickness } \\
\text { with no contrast) and } \\
\text { MRI used in creation } \\
\text { of consensus; Use of } \\
\text { multi-slice CT } \\
\text { scanning with MRI } \\
\text { recommended. }\end{array}$ & $\begin{array}{l}\text { Patient } \\
\text { positioned } \\
\text { supine with } \\
\text { custom Vac- } \\
\text { Lok device; } \\
\text { Bladder } \\
\text { comfortably } \\
\text { full; Empty } \\
\text { rectum (w } \\
\text { Milk of } \\
\text { magnesia. }\end{array}$ & Sagittal CT & $\begin{array}{l}\text { Not } \\
\text { Discussed }\end{array}$ & $\begin{array}{l}\text { CTV: Extended to include } 1 \mathrm{~cm} \\
\text { beyond the gross recurrent disease, } \\
\text { and visible surgical clips located } \\
\text { outside boundaries, excluding high } \\
\text { lymphadenectomy vessel clips. PTV: } \\
\text { Around superior (cranial) CTV: } 15 \\
\text { mm superior-inferior [SI] and } \\
\text { anterior-posterior [AP] and } 12 \mathrm{~mm} \\
\text { right-left [RL]; Around inferior } \\
\text { (caudal) CTV: } 11 \mathrm{~mm} \mathrm{SI} \mathrm{and} \mathrm{AP} \mathrm{and} \\
\text { 8mmRL. }\end{array}$ \\
\hline $\begin{array}{l}\text { FROGG- } \\
\text { RANZCR }\end{array}$ & $\begin{array}{l}\text { Imaging used to } \\
\text { create consensus } \\
\text { not discussed; Use } \\
\text { of multi-slice CT } \\
\text { (2.5-3mm thickness - } \\
\text { intravenous contrast } \\
\text { with delayed } \\
\text { scanning) and/or } \\
\text { MRI fusion } \\
\text { recommended (If }\end{array}$ & $\begin{array}{l}\text { Bladder } \\
\text { comfortably } \\
\text { full; Empty } \\
\text { rectum; } \\
\text { Patient } \\
\text { positioning } \\
\text { not } \\
\text { discussed. }\end{array}$ & $\begin{array}{l}\text { Contrast } \\
\text { enhanced } \\
\text { CT or MRI }\end{array}$ & $\begin{array}{l}\text { Rectum; } \\
\text { Bladder }\end{array}$ & $\begin{array}{l}\text { CTV: Ensure a minimum } 2 \mathrm{~cm} \\
\text { margin from posterior extent of the } \\
\text { CTV to posterior rectal wall. PTV: A } \\
10 \mathrm{~mm} \text { margin around the CTV or } \\
5 \mathrm{~mm} \text { margin on post boarder (if } \\
\text { rectal dose is high). }\end{array}$ \\
\hline
\end{tabular}




\section{Cureus}

\begin{tabular}{|c|c|c|c|c|c|}
\hline EORTC & $\begin{array}{l}\text { Imaging used in } \\
\text { creating consensus } \\
\text { not discussed. Use } \\
\text { of multi-slice CT } \\
\text { recommended. }\end{array}$ & $\begin{array}{l}\text { Bladder } \\
\text { comfortably } \\
\text { full or } \\
\text { empty; } \\
\text { Empty } \\
\text { rectum; } \\
\text { Patient } \\
\text { positioning } \\
\text { not } \\
\text { discussed. }\end{array}$ & $\begin{array}{l}\text { VUA } \\
\text { visualization } \\
\text { not } \\
\text { discussed; } \\
\text { Used penile } \\
\text { bulb as } \\
\text { inferior } \\
\text { border } \\
\text { reference. }\end{array}$ & $\begin{array}{l}\text { Rectum; } \\
\text { Bladder }\end{array}$ & $\begin{array}{l}\text { CTV: } 5 \mathrm{~mm} \text { in all directions (except } \\
\text { the rectal wall) to account for } \\
\text { microscopic extension. } \\
\text { Supplementary } 5 \mathrm{~mm} \text { in posterior } \\
\text { and lateral directions in presence of } \\
\text { incompletely resected extracapsular } \\
\text { tumor extension, excluding rectal } \\
\text { wall. Supplementary } 5 \mathrm{~mm} \text { in } \\
\text { direction of microscopically involved } \\
\text { tumor margins as reported by } \\
\text { pathologist (except rectal wall). PTV: } \\
\text { A minimum of } 5 \mathrm{~mm} \text { in all directions } \\
\text { to account for organ motion. }\end{array}$ \\
\hline RTOG & $\begin{array}{l}\mathrm{CT} \text { ( } 3 \mathrm{~mm} \text { thickens - } \\
\text { no contrast) used in } \\
\text { creation of } \\
\text { consensus. }\end{array}$ & $\begin{array}{l}\text { Patient } \\
\text { positioned } \\
\text { supine; } \\
\text { Bladder } \\
\text { comfortably } \\
\text { full; Empty } \\
\text { rectum. }\end{array}$ & $\begin{array}{l}\text { Sagittal CT; } \\
\text { MRI can } \\
\text { improve } \\
\text { visualization } \\
\text { if available. }\end{array}$ & $\begin{array}{l}\text { Not } \\
\text { discussed }\end{array}$ & Not discussed \\
\hline
\end{tabular}

\section{TABLE 5: Additional Consensus Guideline Information}

Abbreviations: $\mathrm{PMH}=$ Princess Margaret Hospital; EORTC = European Organization for Research and Treatment of Cancer; RTOG = Radiation Therapy Oncology Group; FROGG-RANZCR = The Faculty of Radiation Oncology Genito-Urinary Group part of the Royal Australian and New Zealand College of Radiologists; CT = Computed Tomography; MRI = Magnetic Resonance Imaging; VUA = Vesicourethral Anastomosis; CTV = Clinical Target Volume; PTV = Planning Target Volume.

Multi-slice CT scans were used in the creation of the consensus guidelines by PMH and the RTOG [17, 22]. The use of MRI with or without Positron Emission Tomography (PET) fusion was recommended by PMH and FROGG for delineating treatment plan contours [17, 19]. The importance of effectively defining the vesicourethral anastomosis was identified as an important step in the delineation of postoperative prostate radiotherapy contours in the publications from PMH, RTOG and FROGG [17, 19, 22]. The FROGG and EORTC consensus statements contained recommendations regarding contouring of the OARs [21, 23]. There were additional CTV and Planning Target Volume (PTV) recommendations from PMH, FROGG and the EORTC $[17,19,21,23]$.

\section{Conclusions}

After reviewing the consensus contouring guidelines for postoperative prostate cancer radiation therapy that were available in the literature, it is clear that there is some disagreement with regards to what anatomical borders should be used for delineating an appropriate prostate bed CTV. There were many similarities in the methodology used in the creation of the atlases, although some atlases were more detailed than others. The validation studies performed using the consensus atlases were done on a small number of patients and tended to focus on inter-observer reproducibility of the newly adopted guidelines relative to a previous standard. The results of these studies seemed inconclusive as to whether or not the consensus guidelines improved inter-observer reproducibility in the creation of target volumes 
or any other clinically important outcomes. Additional studies comparing the reproducibility of the various guidelines as well as the performance of these guidelines on clinically important outcomes when used in a variety of clinical sites are needed so that physicians can better decide which atlas, or part of an atlas, to adopt into their practice.

\section{Additional Information}

\section{Disclosures}

Human subjects: All authors have confirmed that this study did not involve human participants or tissue. Animal subjects: All authors have confirmed that this study did not involve animal subjects or tissue. Conflicts of interest: In compliance with the ICMJE uniform disclosure form, all authors declare the following: Payment/services info: All authors have declared that no financial support was received from any organization for the submitted work. Financial relationships: All authors have declared that they have no financial relationships at present or within the previous three years with any organizations that might have an interest in the submitted work. Other relationships: All authors have declared that there are no other relationships or activities that could appear to have influenced the submitted work.

\section{References}

1. Do LV, Do TM, Smith R, Parker RG: Postoperative radiotherapy for carcinoma of the prostate: impact on both local control and distant disease-free survival. Am J Clin Oncol . 2002, 25:1-8.

2. Thompson IM, Tangen CM, Paradelo J, et al.: Adjuvant radiotherapy for pathological T3N0M0 prostate cancer significantly reduces risk of metastases and improves survival: Long-term followup of a randomized clinical trial. J Urol . 2009, 181:956-62.

3. Bolla M, van Poppel H, Collette L, et al: Postoperative radiotherapy after radical prostatectomy: a randomised controlled trial (EORTC trial 22911). Lancet. 2005, 366:572-78.

4. Collette L, van Poppel H, Bolla M, et al: Patients at high risk of progression after radical prostatectomy: do they all benefit from immediate post-operative irradiation? (EORTC trial 22911). Eur J Cancer . 2005, 41:2662-72.

5. Wiegel T, Bottke D, Willich N, et al: Phase III results of adjuvant radiotherapy (RT) versus "wait and see" in patients with pT3 prostate cancer following radical prostatectomy (RP) (ARO 96-02/AUO AP 09/95). J Clin Oncol . 2005, 23:4513.

6. Choo R, Hruby G, Hong J, et al: Positive resection margin and or pathologic T3 adenocarcinoma of prostate with undetectable postoperative prostate-specific antigen after radical prostatectomy: to irradiate or not?. Int J Radiat Oncol Biol Phys. 2002, 52:674-80.

7. Leibovich BC, Engen DE, Patterson DE, et al: Benefit of adjuvant radiation therapy for localized prostate cancer with a positive surgical margin. J Urol. 2000, 163:1178-82.

8. Vicini FA, Ziaja EL, Kestin LL, et al: Treatment outcome with adjuvant and salvage irradiation after radical prostatectomy for prostate cancer. Urology . 1999, 54:111-17.

9. Trock BJ, Han M, Freedland SJ, et al: Prostate cancer-specific survival following salvage radiotherapy vs observation in men with biochemical recurrence after radical prostatectomy. JAMA. 2008, 299:2760-69.

10. Stephenson AJ, Shariat SF, Zelefsky MJ, et al: Salvage radiotherapy for recurrent prostate cancer after radical prostatectomy. JAMA . 2004, 291:1325e-1332.

11. Thompson IM Jr., Tangen CM, Paradelo J, et al: Adjuvant radiotherapy for pathologically advanced prostate cancer: A randomized clinical trial. JAMA. 2006, 296:2329-35.

12. Mitchell DM, Perry L, Smith S, Elliott T, Wylie JP, Cowan RA, Livsey JE, Logue JP: Assessing the effect of a contouring protocol on postprostatectomy radiotherapy clinical target volumes and interphysician variation. Int J Radiat Oncol Biol Phys . 2009, 75:990-98.

13. Lawton CA, Michalski J, El-Naqa I, Kuban D, Lee WR, Rosenthal SA, Zietman A, Sandler H, Shipley W, Ritter M, et al: Variation in the definition of clinical target volumes for pelvic nodal conformal radiation therapy for prostate cancer. Int J Radiat Oncol Biol Phys. 2009, 74:377-82.

14. Lawton CA, Michalski J, El-Naqa I, Buyyounouski MK, Lee WR, Menard C,O’Meara E, Rosenthal SA, Ritter M, Seider M: RTOG GU Radiation oncologyspecialists reach consensus on 
pelvic lymph node volumes for high-risk prostate cancer. Int J Radiat Oncol Biol Phys . 2009, 74:383-87.

15. Livsey JE, Wylie JP, Swindell R, Khoo VS, Cowan RA, Logue JP: Do differences in target volume definition in prostate cancer lead to clinically relevant differences in normal tissue toxicity?. Int J Radiat Oncol Biol Phys. 2004, 60:1076-81.

16. Jameson MG, Holloway LC, Vial PJ, Vinod SK, Metcalfe PE: A review of methods of analysis in contouring studies for radiation oncology. J Med Imaging Radiat Oncol . 2010, 54:401-10.

17. Wiltshire KM, Brock KK, Haider MA, Zwahlen D, Kong V, Chan E, Moseley J, Bayley A, Catton C, Chung P, Gospodarowicz M, Milosevic M, Kneebone A, Warde P, and Menard C: Anatomic boundaries of the clinical target volume (prostate bed) after radical prostatectomy. Int J Radiat Oncol Biol Phys. 2007, 69:1090-99.

18. Mitchell DM, Perry L, Smith S, Elliott T, Wylie JP, Cowan RA, Livsey JE, and Logue JP: Assessing the effect of a contouring protocol on postprostatectomy radiotherapy clinical target volumes and interphysician variation. Int J Radiat Oncol Biol Phys . 2009, 75:990-93.

19. Sidhom MA, Kneebone AB, Lehman M, Wiltshire KL, Millar J, Mukherjee RK, Shakespeare TP, and Tai KH: Post-prostatectomy radiation therapy: Consensus guidelines of the Australian and New Zealand Radiation Oncology Genito-Urinary Group. Radiation and Oncology. 2008, 88:10-19.

20. Ost P, De Meerleer G, Vercauteren T, De Gersem W, Veldeman L, Vandecasteele K, Fonteyne $\mathrm{V}$, and Villeirs G: Delineation of the postprostatectomy prostate bed using computed tomography: Interobserver variability following the EORTC delineation guidelines. Int J Radiat Oncol Biol Phys . 2011, 81:e143-e149.

21. Poortmans P, Bossi A, Vandeputte K, Bosset M, Miralbell R, Maingon P, Boehmer D, Budiharto T, Symon Z, van den Bergh ACM, Scarse C, Van Poppel H, and Bolla M: Guidelines for target volume definition in post-operative radiotherapy for prostate cancer, on behalf of the EORTC radiation oncology group. Radiotherapy and Oncology . 2007, 84:121-27.

22. Michalski JM, Lawton C, El Naqa I, Ritter M, O’Meara E, Seider MJ, Lee WR, Rosenthal SA, Pisansky T, Catton C, Valicenti RK, Zietman AL, Bosch WR, Sandler H, Buyyounouski MK, and Ménard C: Development of RTOG consensus guidelines for the definition of the clinical target volume for postoperative conformal radiation therapy for prostate cancer. Int J Radiat Oncol Biol Phys. 2010, 76:361-68.

23. Boehmer D, Maingon P, Poortmans P, Baron MH, Miralbell R, Remouchamps V, Scrase C, Bossi A, and Bolla M: Guidelines for primary radiotherapy of patients with prostate cancer . Radiotherapy and Oncology. 2006, 79:259-69.

24. Warfield SK, Zou KH, Wells WM: Simultaneous truth and per- formance level estimation (STAPLE): An algorithm for the validation of image segmentation. IEEE Trans Med Imaging . 2004, 23:903-21.

25. Allozi R, Li X, White J, Apte A, Tai A, Michalski J, Bosch W, and El Naqa I: Tools for consensus analysis of experts' contours for radiotherapy structure definitions. Radiotherapy and Oncology. 2010, 97:572-78.

26. Brock KK, Dawson LA, Sharpe MB, et al: Application of a novel deformable image registration technique to facilitate classification, tracking and targeting of tumor and normal tissue. 2004, 60:S227.

27. Deasy JO, Blanco AI, Clark VH. : CERR: A computational environment for radiotherapy research. Med Phys. 2003, 30:979-85.

28. Fleiss JL, Levin BA, Paik MC: Statistical methods for rates and proportions. Hoboken (ed): Wiley, N.J.; 2003. 